\title{
Acercamiento a la prosa de intensidades de Alberto Ruy Sánchez desde la razón poética de María Zambrano
}

Approach to Alberto Ruy SÁnchez's prose of intensities FROM MaRía Zambrano's POETICAL REASON

Laiza Sabrina de la Torre-Zepeda*

* Universidad Autónoma del Estado de México, México Correo-e: laizadetorre@gmail.com Recibido: 15 de abril de 2020 Aprobado: 9 de diciembre de 2020

Resumen: Se presenta un acercamiento a la prosa de intensidades de Alberto Ruy Sánchez con la finalidad de analizarla desde la razón poética de María Zambrano. Se toma en consideración la obra del Quinteto de Mogador (2015), la cual está compuesta por cinco libros: Los nombres del aire (1987), Nueve veces el asombro (2005), En los labios del agua (1996), Los jardines secretos de Mogador (2001) y La mano del fuego (2007). Se hace énfasis en la escritura propuesta por Ruy Sánchez donde la intensidad se vive a cada momento. Se explica la manera en que poesía y pensamiento se unen para revelar una realidad colmada de asombro, en la que destaca la entrega del poeta enamorado, quien todo lo espera, tal como los personajes de esta obra.

Palabras clave: literatura latinoamericana; literatura contemporánea; literatura de ficción; análisis literario; estilo literario; forma y género literario; poesía; prosa; filosofía

Abstract: An approach to Alberto Ruy Sánchez's prose of intensities is presented with a view to analyzing it from María Zambrano's poetical reason. The work Quinteto de Mogador [Quintet of Mogador] is considered; it is composed of five books: Nueve veces el asombro [Nine times the astonishment]; Los nombres del aire [Mogador]; En los labios del agua [n the lips of water]; Los jardines secretos de Mogador [The Secret Gardens of Mogador] and La mano del fuego [Hand of fire]. Emphasis is made on the writing proposed by Ruy Sánchez, in which intensity is experienced at all times. It is explained the way in which poetry and thinking join to disclose a reality full of amazement, in which the delivery of an enamored poet is revealed, who waits for things to occur, such as this novel's characters.

Keywords: Latin American literature; contemporary literature; fiction; literary analysis; literary style; literary forms and genres; poetry; prose; philosophy 
INTRODUCCIÓN

El agua ensimismada
ipiensa o sueña?
El árbol que se inclina buscando sus raíces,
el horizonte,
ese fuego intocado,
¿se piensan o se sueñan?
María Zambrano

Alberto Ruy Sánchez ha dedicado gran parte de su obra a crear una ciudad colmada de pasiones, donde habitan seres que viven a la medida de sus deseos. Mogador es un lugar mágico y soñado lleno de cosas asombrosas, desde las cabras que penden de los árboles de thuja hasta la traza geométrica del lugar. La visita del escritor a la ciudad de Essaouira, en Marruecos, antiguo puerto de Mogador, generó en él un choque de emociones que culminó en la escritura de un ciclo dedicado a este sitio.

Alberto Ruy Sánchez Lacy nació en 1951 en la Ciudad de México. De pequeño vivió en el desierto del noroeste de México, en la parte sur de Baja California. Este lugar, significativo para su obra, forma una porción de esa memoria involuntaria a la que alude constantemente y, a la vez, es punto de unión con el desierto del Sahara. En París realizó un doctorado en Letras, para cuyo trabajo de grado fue dirigido por Roland Barthes. Es director general de la revista Artes de México desde 1988. Ha sido condecorado en diversas ocasiones: con el Premio Xavier Villaurrutia en 1987; en 2000, el gobierno francés lo nombró miembro de la Orden de las Artes y Letras por su obra literaria y editorial; en 2006 obtuvo el Premio Nacional Juan Pablos al Mérito Editorial; en 2017 recibió el Premio Nacional de Artes y Literatura; y en 2019, el premio Caracol de Plata. Narrador, poeta, ensayista y editor, su obra se ha traducido a varios idiomas. Su primera novela, Los nombres del aire (1987), inaugura el Quinteto de Mogador (2015), que también reúne Nueve veces el asombro (2005), En los labios del agua
(1996), Los jardines secretos de Mogador (2001) y La mano del fuego (2007).

Por su parte, María Zambrano, filósofa y escritora española, nació en 1904 en la ciudad de Málaga y murió en Madrid en 1991. Su adolescencia trascurrió en Segovia. Cursó estudios de Filosofía en Madrid, donde tomó clases con José Ortega y Gasset, maestro y referente intelectual en su formación. Participó en movimientos estudiantiles y colaboró en diversos periódicos. Su primera obra, Horizonte del liberalismo (1930), fue escrita en esta época. En 1938 fue enviada al exilio por defender la España republicana durante la Guerra Civil. En los años siguientes entabló amistad con integrantes de la generación del 27. Visitó numerosos países, entre ellos México, donde impartió clases de Filosofía en la Universidad Michoacana de San Nicolás de Hidalgo, en Morelia. Conoció a Octavio Paz y a León Felipe. Publicó también Pensamiento y poesía en la vida española (1939) y Filosofia y poesía (1939), donde afirma que la razón poética se conforma por dos llamas vivas del ser que, en la búsqueda de la reconciliación, se fusionan para multiplicar las contradicciones del hombre.

El presente estudio constituye un acercamiento a la prosa de intensidades de Alberto Ruy Sánchez desde la propuesta de María Zambrano. En la razón poética, poesía y pensamiento se entretejen para formar una sola visión del mundo, revelando una realidad para el ser humano, razón inserta en la vida llena de asombro. Lo mismo sucede en la prosa de intensidades, que lleva al lector a sentir el momento colmado de sensaciones y emociones nuevas. El asombro es la puerta de entrada a esta escritura y a la ciudad-mujer inaccesible que es Mogador.

ENTRE LA PROSA DE INTENSIDADES Y LA RAZÓN POÉTICA

Ruy Sánchez explica la razón de su escritura en $A l$ filo de las hojas (1988), donde expone el impulso 
narrativo que utiliza José Martínez Sotomayor en su novela La rueca del aire (1930). Otros ejemplos se encuentran en la prosa de autores modernistas, como Gilberto Owen y Xavier Villaurrutia. Esta forma de novelar no es exclusiva de Ruy Sánchez, quien sólo se deja llevar por las intensidades que le permite la palabra, convirtiéndose en un poeta de la prosa y marcando la cadencia de las imágenes que están volcadas en el texto.

El lector de la prosa de intensidades es capaz de leer poesía, adentrándose en las palabras sobresaltadas que se revelan en ese instante, producto de intensidades que se viven momento a momento. Asimismo, desea seguir en la exploración de más sensaciones en una especie de espiral interminable donde se manifiesta la revelación poética del cuerpo del amado, un ser inaccesible. A ello se une la metáfora de la ciudad de Mogador, a cuyas calles laberínticas el lector aspira a entrar, siempre encaminado por la misma avidez y emociones que se experimentan cuando se pretende conocer al amante.

La prosa de intensidades expresa los anhelos del mundo, los vive a partir de esa complicidad que el lector tiene con el texto. La ciudad revela las laberínticas edificaciones del deseo y permanece en la búsqueda de lo inexplicable que todos poseemos. En la obra de Alberto Ruy Sánchez hay una forma de escritura, un lenguaje que habla de una urbe imaginaria, la cual se encuentra en todas partes y principalmente en uno mismo, lugar colorido donde se experimenta un choque de imágenes envolventes. Con tan sólo mirar este sitio se quiere habitarlo para siempre y dejarse perder entre sus calles, espirales inagotables de palabras que se ciñen de deseo.

Hay que estar en esa constante indagación de nuevas experiencias, que fluyen de manera siempre tan distinta, para que el anhelo no se apague y siga presente; sentir un instante que va hacia uno mismo, lleno de sensaciones. Esta prosa combina la novela con un poema extenso; leer la narrativa de Ruy Sánchez es remontarse a un universo sensorial conducido por el ritmo de las palabras, un lenguaje que vivifica los sentimientos y nos hace sentirnos como un personaje más de esa ciudad imaginaria, un 'Sonámbulo', en palabras del autor, aquel individuo que se deja conducir por la constante búsqueda de pasiones:

\begin{abstract}
Los Sonámbulos somos cuerpos poseídos por los deseos hambrientos de miles de otras personas que murieron antes de realizar sus sueños. Somos enjambres de sueños, enredaderas de sueño, muchas veces con espinas. Nudos de sueños. Por eso estamos aquí, cumpliendo deseos de personas que no conocimos pero que ahora son los deseos nuestros (295). ${ }^{1}$
\end{abstract}

Con los Sonámbulos, Ruy Sánchez permea de deseo a la palabra. En la aventura amorosa se marca una expresión sensual que conduce por imágenes eróticas y crea un universo sensorial. Todos aquellos viajeros de Mogador son Sonámbulos, seres con un anhelo insaciable de amar, de percibir lo invisible, que viven con un eterno apetito por el otro, una necesidad de poseer y dejarse llevar, de sentir el deseo que está en todo, en cada sensación y emoción, un interminable sentimiento de entrega, de esperar la noche para encontrar al amante.

Así es la prosa de intensidades, un asombro como la poesía, arrebato del momento mediante la experiencia que nos ofrece la lectura, salir de ella y sentirla, vivirla. Sitios como las ciudades se convierten en el cuerpo del amado y viceversa. La exploración se vuelve un encuentro inalcanzable e inacabado. La propuesta de Ruy Sánchez implica también abismarse en el lenguaje de la pasión, del sueño sin fin, una flor que se abre y se convierte en miles de posibilidades, en jardines a la medida del cuerpo que la gente busca para convertirlos en paraíso, semillas del deseo donde la

1 Todas las citas pertenecientes al Quinteto de Mogador corresponden a Ruy Sánchez, 2015, por lo cual sólo se anota el número de página. 
geografía erótica se hace infinita esperando descifrar un secreto.

Al mirar todo lo que está alrededor de Mogador, la ciudad se convierte en la metáfora del erotismo del mundo, en la indagación de aquello imperceptible que se sabe que existe. Esta escritura toca lo invisible, crea un vínculo entre lo tangible y lo intangible en la manifestación imaginaria del cuerpo; invita a aprender siempre algo distinto, a vivir con intensidad todo detalle que se presenta.

La obra de Alberto Ruy Sánchez muestra con su prosa de intensidades la combinación que logra con la poesía y las sensaciones que aparecen al entrar en el espacio narrado. Mogador es la ciudad que se descubre a cada instante y jamás se termina de conocer; siempre hay un nuevo asombro, una exploración, puesto que se trata de un sitio inaccesible que ansiamos poseer. Cada elemento que en él habita constituye un universo que recubre la ciudad: murallas, calles laberínticas, casas y, dentro de ellas, jardines ocultos unos tras otros en una espiral interminable. Este espacio sólo se hace accesible para aquel que gusta de adentrarse en el paraíso sensorial, ver, oler, tocar, gustar, oír, percibir cada instante eternizándolo, deteniéndolo para apreciarlo y sorprenderse con esta experiencia.

La poesía se vivifica en el momento de recrear el texto y apropiarse de él como de un amante deseado, cada vez conduce por caminos inimaginables. Dice Alberto Ruy Sánchez en De cuerpo entero: "mi jardín del tiempo, donde los mejores instantes viven y toman una forma flexible para convertirse en literatura; en ese poema extenso que es la prosa de intensidades" (1992: 49). Sólo la sensación de experimentar el poema produce el placer de sentir libertad. La poesía es un expresar sentimientos, una luz que enciende la piel del lector y penetra profundamente en su cuerpo hasta llegar a las profundidades del ser.

En la obra de Ruy Sánchez se manifiestan instantes recreados en un tiempo fuera del tiempo, elemento que juega una parte importante en su narrativa. En repetidas ocasiones se habla de 'la hora de los amantes', un periodo en que todo parece detenerse. En Nueve veces el asombro se dedica el capítulo III, "Del tiempo en Mogador", a explicar cómo los acontecimientos se demoran al permanecer en esta ciudad. Allí es donde se enlazan las palabras, recurso que utiliza el autor para crear su obra. En este tiempo pausado se muestra cada detalle a partir de imágenes; así, el lector se adentra en la experiencia de permanecer en Mogador, se refugia aquí.

En este sentido, la razón poética de María Zambrano, como la de Ruy Sánchez, constituye una razón vital, en ella se significa un saber originario, aquel que sentimos, que nos recoge y requiere nuestra atención, que nos ayuda a conocer lo más hondo de nuestra existencia y lo más cierto, trasformando el vivir en experiencia. Razón poética y prosa de intensidades se unifican; basta una sola palabra para que se genere una gran cantidad de frases, de instantes poéticos: 'Mogador'.

La obra de Zambrano busca la reconciliación entre decir y pensar, entre poesía y filosofía; asimismo, pretende el encuentro con un sujeto creador donde se identifique la existencia, la verdad y el conocimiento. Zambrano propone una filosofía nueva, cuyo logos traspase los límites de lo racional, conduciéndose hacia la propia experiencia de la vida. En gran parte de su trabajo hace una distinción entre poesía y pensamiento, que corresponden, a su vez, a dos caminos: en la filosofía se da la pregunta, mientras que en la poesía hallamos múltiples respuestas, como explica en El hombre y lo divino:

\footnotetext{
La filosofía se inicia del modo más antipoético: por una pregunta. La poesía lo hará siempre por una respuesta a una pregunta no formulada. El preguntarse es lo peculiar del hombre, el signo de que ha llegado a un momento en que va a separase de lo que lo rodea, algo así como la ruptura de un amor, como el nacimiento (1973: 66-67).
} 
El fin de la filosofía es la búsqueda de cuestionamientos, el de la poesía, dar respuestas, ser espejo en donde se refleja el lector, quien pretende identificar en ella lo que es común a su existencia. Así es como la obra de Zambrano parte de la experiencia del día a día, esa es la sabiduría que le interesa. En este sentido, la filosofía ha de tratar del vivir cotidiano, orientándolo.

De ahí que, con la figura del «poeta», antípoda del filósofo, Zambrano remita tanto a sí misma como creadora de un nuevo método de aprehensión de la realidad, el racio-poético, como aquellos iniciados que alcancen a seguirla en su propio pensamiento. Poeta será, pues, el «nuevo» filósofo que esté en condiciones de sobrepasar la «violencia» de la metafísica clásica y el «espíritu» voluntarista de la metafísica moderna (Bundgard, 2000: 216).
Para Zambrano, la filosofía no es una cuestión de conceptos, sino de símbolos que deben abordar los problemas esenciales de la trascendencia y los grandes misterios de la vida. La autora hace un análisis de la razón poética, que es una relevancia del 'saber del alma' unida a la reflexión sobre la esperanza en la existencia. Así, constituye un modo humano de interpretar, una razón unitiva, integradora, con una mirada creativa, capaz de desvelar el origen, que es armonía.

El pensar poético es acción - mirar, contemplar-, don, gracia que nos abre el universo y permite liberar al individuo, ver la poesía como revelación, sentimiento e idea. De esta manera, el lenguaje se despliega dentro del texto para significar la geometría de lo indecible, esa es la palabra poética.

En la prosa de intensidades, la respuesta a esta razón poética se encuentra en la experiencia

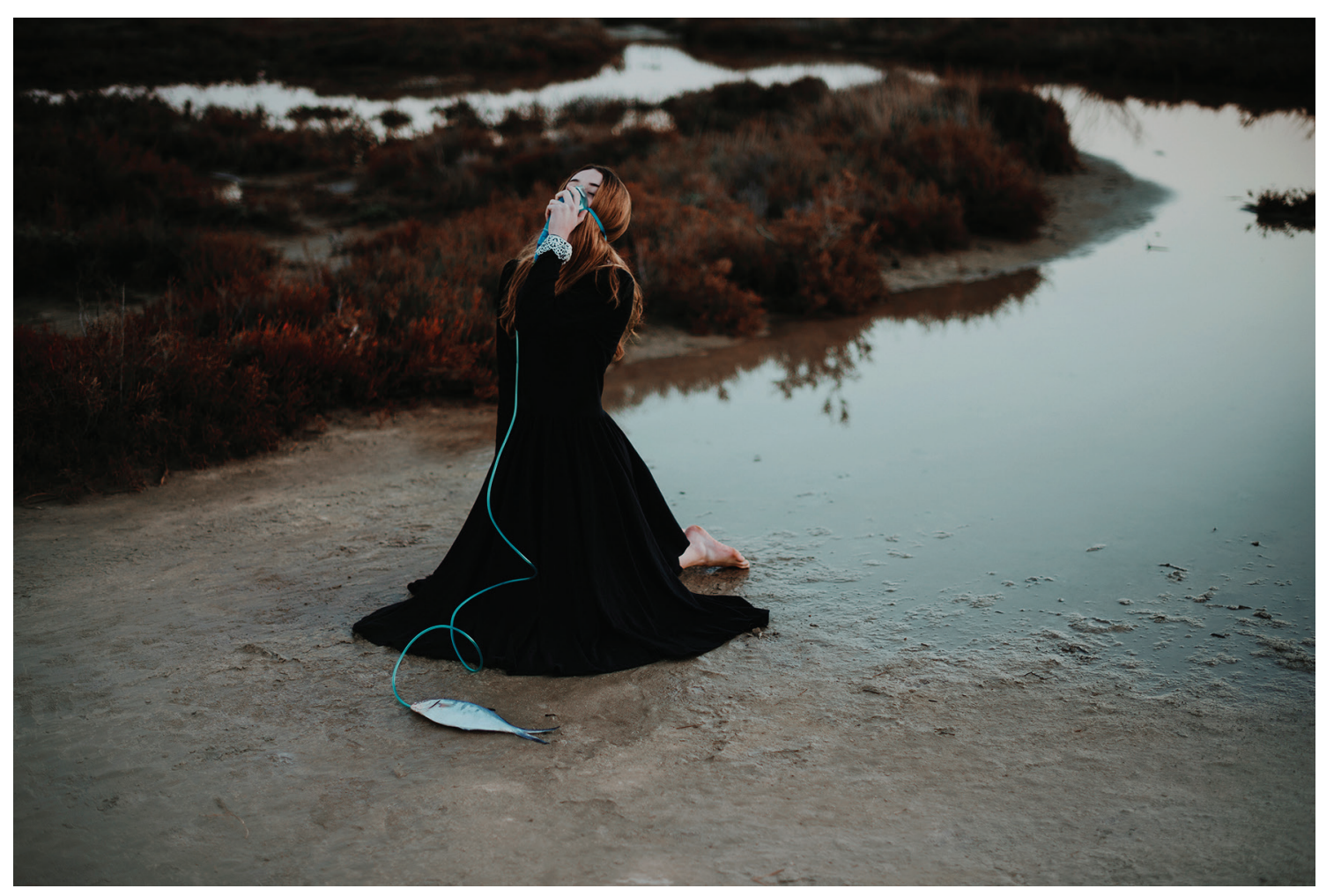

Oxygen (2017) Fotografía Fine Art: Frank Diamond.

Prohibida su reproducción en obras derivadas. 
que viven los enamorados, apasionados eternos de Mogador, desde la búsqueda constante, la espera y el anhelo de estar juntos hasta su unión, esa hora en que los amantes traen los sueños enredados. Cada momento se vive con emoción y deseo, los sentidos cobran importancia, son la llama que enciende la vida.

Todo este universo sensorial que se muestra en el Quinteto de Mogador es posible, dice Graciela Monges Nicolau, a propósito de la novela LoS nombres del aire:

\begin{abstract}
El sentimiento poético, después de haber pasado por una especie de destilación alquímica de la materia onírica, proyectado a través de la unión de los significados, de un constante contrapunto entre significado y significante, y del encadenamiento de las imágenes o símbolos en términos de Frye, que considera a ambas como unidades de significado o estructura con implicaciones conceptuales, es justamente lo que esta obra nos trasmite, y en ello estriba el arte de la prosa de Ruy Sánchez y el placer que despierta su lectura (2004: 57).
\end{abstract}

La obra de Ruy Sánchez muestra las sensaciones que se tienen al entrar a un espacio nuevo como Mogador; la ciudad se descubre y no termina por revelarse, es un lugar que se puede sentir en uno mismo. Sitio impenetrable y anhelado, se hace accesible para aquel que se adentra en el paraíso sensorial y percibe cada instante para apreciarlo y maravillarse con esa experiencia. Esto es lo que trata la poesía: vivir intensamente a partir del asombro que generan las imágenes puestas en cada palabra.

La literatura trasporta a nuevos lugares, por ello Mogador atrapa con su perfecta geometría hecha a la medida del deseo, donde la dimensión de las pasiones es visible y en el que el sueño y la vigilia se unifican. Esta forma peculiar de escribir de Alberto Ruy Sánchez constituye, en su conjunto, un poema que exalta la belleza del cuerpo humano y el asombro de poseerlo. El texto envuelve, se fija en un espacio imaginario donde, por un instante, toca al lector a profundidad y lo lleva a vivir en plenitud. Así es el territorio que fija la prosa de intensidades:
A Mogador la inaccesible, a la ciudad arrinco- nada de Mogador, sólo se llegaba por agua. Más de una vez me dijeron y con diferentes palabras, que eran necesarias las pausas del mar para ir reteniendo en los ojos la piedra blanca de los muros que la rodean. Así la vi desde el agua: todo el peso del sol deposita- do en cada grano de sus piedras, como si la luz que ciega y su intermitencia le fueran impo- niendo al que llega el tiempo y la manera de acercarse (335).

La obra de Alberto Ruy Sánchez se encuentra permeada por esta escritura. Las imágenes poéticas, que nunca se cansa de usar, se presentan como metáforas, nos conmueven y provocan, desencadenan la reflexión, la exploración de las emociones, transformándose en el lenguaje del instante. Como afirma Bachelard: "La poesía es una metafísica instantánea. En un breve poema, debe dar una visión del universo y el secreto de un alma, un ser y unos objetos, todo al mismo tiempo" (2014: 93).

Basta una frase para adentrarnos en un mundo de intensidades: "Ella es como un río delgado que entra en uno más grande y lo cruza sin mezclarse" (Ruy Sánchez, 1994: 36). Mogador y la amante se fusionan, crean un universo propio, lleno de asombro. Podríamos dar muchos ejemplos de esta prosa, pero es suficiente decir que toda la obra del mexicano cultiva esta particular escritura, y de igual modo, es incansable como Mogador y la recreación de esta ciudad-cuerpo, laberinto de deseos, un lugar inaccesible.

En esta experiencia de sorpresa y revelación cabe la palabra de Alberto Ruy Sánchez: "en la prosa de intensidades, la imagen domina sobre cualquier anécdota, y ésta sola es aceptada cuando sabe convertirse en imagen, es decir, 
en materia de la poesía” (1988: 72). En su libro, Cuatro escritores rituales, el mexicano afirma que: "la aparición del instante poético, en verso o en prosa, es equivalente a una revelación, 'a una porción de eternidad'. Escribir es, para algunos escritores, provocar esa revelación” (Ruy Sánchez, 2001: 10). La búsqueda de estos lugares internos se presenta cuando la imagen se une a la poesía dando lugar a la imagen poética, que según Bacherlard: "puede ser el germen de un mundo, el germen de un universo imaginado ante las ensoñaciones de un poeta" (1993: 10).

Para Octavio Paz, el sentido de la imagen poética es la imagen misma, una presencia instantánea y total que requiere una valoración de aquello que esconde, que promete mediante la palabra: "la imagen dice lo indecible: las plumas ligeras son piedras pesadas. Hay que volver al lenguaje para ver cómo la imagen puede decir lo que, por naturaleza, el lenguaje parece incapaz de decir" (2010: 106). El poema trasciende la palabra, nos queda la imagen, que nos conduce a la percepción para darle sentido al objeto y se desborda en una pluralidad de significados.

La prosa de intensidades surge a partir de una búsqueda; el viaje a Mogador significa el reconocimiento del lugar, hacerlo propio para mostrarlo a los demás, lo que provoca en el autor una gama de emociones desencadenada por la travesía imaginaria. Alberto Ruy Sánchez afirma en De cuerpo entero:

La llegada al puerto, el pausado desembarque en un aire lleno de agua, el tiempo detenido en el que habíamos entrado, las voces del mercado mezcladas con el canto del mar eran una experiencia irremplazable. Ahí mismo sentí que eso valía la pena tratar de escribir. Que esos momentos eran mi paraíso, y que tenía que ser capaz de dar cuenta de ellos en palabras que fueran fieles a su espíritu de intensidad más que a su anécdota. Ese fue para mí el comienzo de 'la prosa de intensidades' (1992: 44-45).
Esta escritura está permeada de tonalidades altas y bajas, como la vida. Un vaivén de emociones y sensaciones, así como expresiones que conducen a imágenes, son el terreno donde se desenvuelve la prosa de intensidades, como explica Ruy Sánchez en su libro Al filo de las hojas:

Para hacerse comunicables, las intensidades tienen que tomarse a sí mismas como objeto de expresión. Así forman la imagen de un círculo $o$ 'de un movimiento circular incesante, como las olas del mar'. Es decir que la intensidad, para comunicarse, se tiene que volver imagen: como la prosa poética, que avanza por medio de imágenes y no por anécdotas que se encadenen y transcurran a lo largo de la historia (1988: 65).

Mogador es la amante que se desea. Viajar por ella nos conduce por los caminos del anhelo, como un impulso en una exploración minuciosa que lleva al asombro, revelación en donde la palabra surge para maravillar. Por ello, aparece la cartografía, técnica de trazar mapas, el arte minucioso de buscar un esbozo perfecto. Las mismas caligrafías que enlazan la escritura mogadoriana evocan este boceto estético que no para de fascinar. Las manos de las mujeres perfectamente dibujadas con henna, símbolos de protección, expresan rituales, la conexión entre lo divino y lo mundano, la baraka, una bendición que da continuidad a la vida. La mano abierta de Jamsa, mano que recibe, que cobija y toca, recuerda en sus cinco puntos a la luna y la fertilidad.

En Mogador hay fascinación en la palabra, se contempla un engranaje de pasión y deseo, asombro que surge en el alma como un principio activo en el hombre. Este efecto es provocado por la sed de sentido, movimiento, reflexión y admiración. Desde esta postura, la vida da un giro, lo que antes pudo ser visto como ocultamiento y olvido ahora se convierte en una gama de posibilidades vinculadas a la experiencia y la indagación del 
ser. El asombro es finito, pero si se vive como un pasajero en la espiral de anhelos y entusiasmos, deriva en un continuo maravillarse ante el mundo, da pauta para la apertura al saber, constituye una invitación al reconocimiento.

Los amantes, con sus besos, redescubren sus cuerpos y fijan la cartografía perfecta; en silencio, se impregnan de pasión, sensaciones y emociones que conducen al instante que no para de seducir. Estos seres son entonces como la ciudad de Mogador que llevamos dentro y sus murallas delinean el límite del brío en que se habitan.

Alberto Ruy Sánchez escribe su obra a partir de la exploración del deseo femenino, fruto de escuchar mil y una historias de mujeres jardineras, que se expresan con más precisión en LoS jardines secretos de Mogador. Hay que destacar que todo el conjunto del Quinteto hace énfasis en esta parte del deseo femenino, aquel que se sabe expresar con sutileza y florece poco a poco para convertirse en fuego. La llama de la pasión se congrega en la poética del autor. Esta narrativa aborda imagen tras imagen, explorando diversas formas de la escritura, como explica Carmen Dolores Carrillo Juárez:

La prosa de intensidades es un género que deja en libertad a Ruy Sánchez para explorar en el ámbito poético en prosa y recurrir a los géneros en prosa que le facilitan el movimiento de avance y regreso. De esta manera, la novela tiene momentos ensayísticos y de crónica entre la narración hasta llegar al poema en prosa como momento de gran intensidad [...] La escritura se despliega en ritmos de imágenes como las caricias crecen en el cuerpo del otro (2004: 92).

Ruy Sánchez indaga en un género híbrido, el $a d a b$ árabe, género de géneros, mezcla de ensayo, poesía y relato:

El adab cultiva un ritmo de viajes rigurosos dentro de la obra, pero al mismo tiempo se ocupa por ir un poco a la deriva como el ensayo literario o el jazz, yendo al presente y al pasado, haciendo asociaciones sorpresivas (760).

El Quinteto de Mogador se compone de piezas sueltas donde se tejen los deseos amorosos de los Sonámbulos, como en un rizoma. Los personajes se unen en el amor, son ramas que crecen, se complementan y añoran. Así, encontramos historias enlazadas que se fusionan, un texto evoca a otro, se trata de libros que se pueden leer por separado, pero unidos encuentran un sentido total. Para Graciela Monges Nicolau:

\begin{abstract}
La sexualidad adquiere el carácter de humana en la medida en que la penetra, la invade y la impregna la exigencia propiamente humana; por eso siempre se puede apreciar en ella cierta nota de posesión, cierto matiz de dominio y también un afán de estima y reconocimiento mutuo, sentimientos que el lector puede apreciar en los textos de Ruy Sánchez (2004: 87).
\end{abstract}

Esta prosa va más allá de la denominada literatura erótica, es una escritura que refleja un profundo encuentro con el ser, un acercamiento a la intensidad de vivir cada instante y percibir los diferentes estados del amor, por lo que se asocia a la escritura árabe, esos kamasutras de los que se hace mención en el Quinteto de Mogador, como El collar de la paloma, de Ibn Hazm, y el Tratado del amor, de Ibn Arabi. Al respecto, dice Mario Gingras:

\begin{abstract}
Sobre la cuestión de la estructura de su narrativa, Ruy Sánchez explica cómo literalmente se tiene que manejar la trama para alcanzar la forma espiral que privilegió en la mayoría de sus textos. Es que esta forma se asemeja bastante a la antigua literatura arábigo andaluza que también funciona en espiral (2006: 9).
\end{abstract}

El encuentro con la cultura de Essaouira, como aporte a la prosa de intensidades, es como el interior de una caja de madera de thuya, donde 
se puede guardar lo que se quiera. Su carácter ilusorio y vacío permite a las personas depositar en ella una parte de sus anhelos y colmarla de vivacidad. Por eso Mogador, el lugar que algunos dicen que no existe pero se lleva muy dentro, aquel que se halla en la costa atlántica del norte de África, el del nombre silbante 'SsueiRA', la urbe del deseo, es la materia sobre la cual Alberto Ruy Sánchez ha construido a lo largo de muchos años otra ciudad, imaginaria y erótica, donde suceden sus novelas, relatos y poemas, que se enlazan en el cuerpo de quien las lee y se apropia de ellos, colmando sus deseos de intensidades. Es importante abordar esta escritura que se asemeja a la arabigoandaluza en cuanto a la espiral, tal como se muestra en las calles laberínticas del lugar, en su traza geométrica y en la estructura que denotan los intertítulos, como nueve veces nueve relatos, que componen la introducción al Quinteto, Nueve veces el asombro, y las historias jardineras que el amante de Jassiba le cuenta cada noche en Los jardines secretos de Mogador.

En los textos de Ruy Sánchez hay un elemento que, como la ciudad amurallada, se encuentra constituido por un mandala: los zelliges, azulejos árabes que por separado funcionan por sí solos, pero juntos se concatenan para recrear la magia y sentido en su totalidad. Una perfecta armonía se presenta en estas figuras que se asocian a la imagen del caleidoscopio, por ser piezas que se organizan en infinitas maneras; esa estructura permite la construcción de representaciones gráficas que cambian constantemente. Según Michael Abeyta, la prosa de intensidades refleja esta geometría:

En sus novelas Ruy Sánchez busca la misma fluidez dinámica que se encuentra en las catedrales góticas y que depende de los componentes mínimos de la ensambladura, de la conectividad entre ellos. Como entre los obreros que levantan las catedrales, la geometría de la narrativa de Ruy Sánchez no se extiende desde una estructura total, sino que depende de la posibilidad conectiva de lo que él llama las intensidades, imágenes poéticas que tendrían la misma función que los cortes de los constructores de las catedrales. Por eso, Ruy Sánchez suele comparar sus narraciones con la artesanía (2007: 14).

Tal como el personaje de Zaydún, en La mano del fuego, Alberto Ruy Sánchez es un artesano, aprendiz eterno del deseo en la búsqueda constante de intensidades movidas por el asombro que la existencia trae a su paso; cada instante es para él un goce, un momento para la prolongación del amor.

El Quinteto de Mogador constituye la indeterminación del fuego en la palabra. Esto es lo que provoca la fascinación, como una regla de la vida y de la creación. Las cabras en los árboles a la entrada del lugar, el fuego que funde el alfarero entre el barro mezclado con las cenizas del Sonámbulo en espera eterna de su amada, la libélula capaz de sentir la pasión total en su cuerpo constituyen las imágenes que guían la atracción y el embrujo de la ciudad amurallada: "su experiencia del fuego es el secreto radical, el que de verdad no puede ser dicho nunca" (783). En este ardor, la palabra permanece muda y permite el instante de asombro infinito.

La experiencia que se manifiesta en el Quinteto constituye una espiral interminable de pasiones y asombros que inicia desde la entrada a Mogador, pues una vez estando ahí jamás se puede salir, el cuerpo se funde con las calles laberínticas en las que se enciende el calor interior.

Profundizar en la prosa de Ruy Sánchez provoca sentir y vivir intensamente a partir de la fascinación de las palabras que expresan las imágenes; el lector indaga en la experiencia para ser partícipe de esa poesía viva conformada por las historias entrelazadas de los enamorados. Tal como concibe María Zambrano, la poesía conduce a la entrega, también a enamorarse. El poeta espera por lo que quiere decir, anhela recibir lo que da. El amor es la clave de la salvación de este 


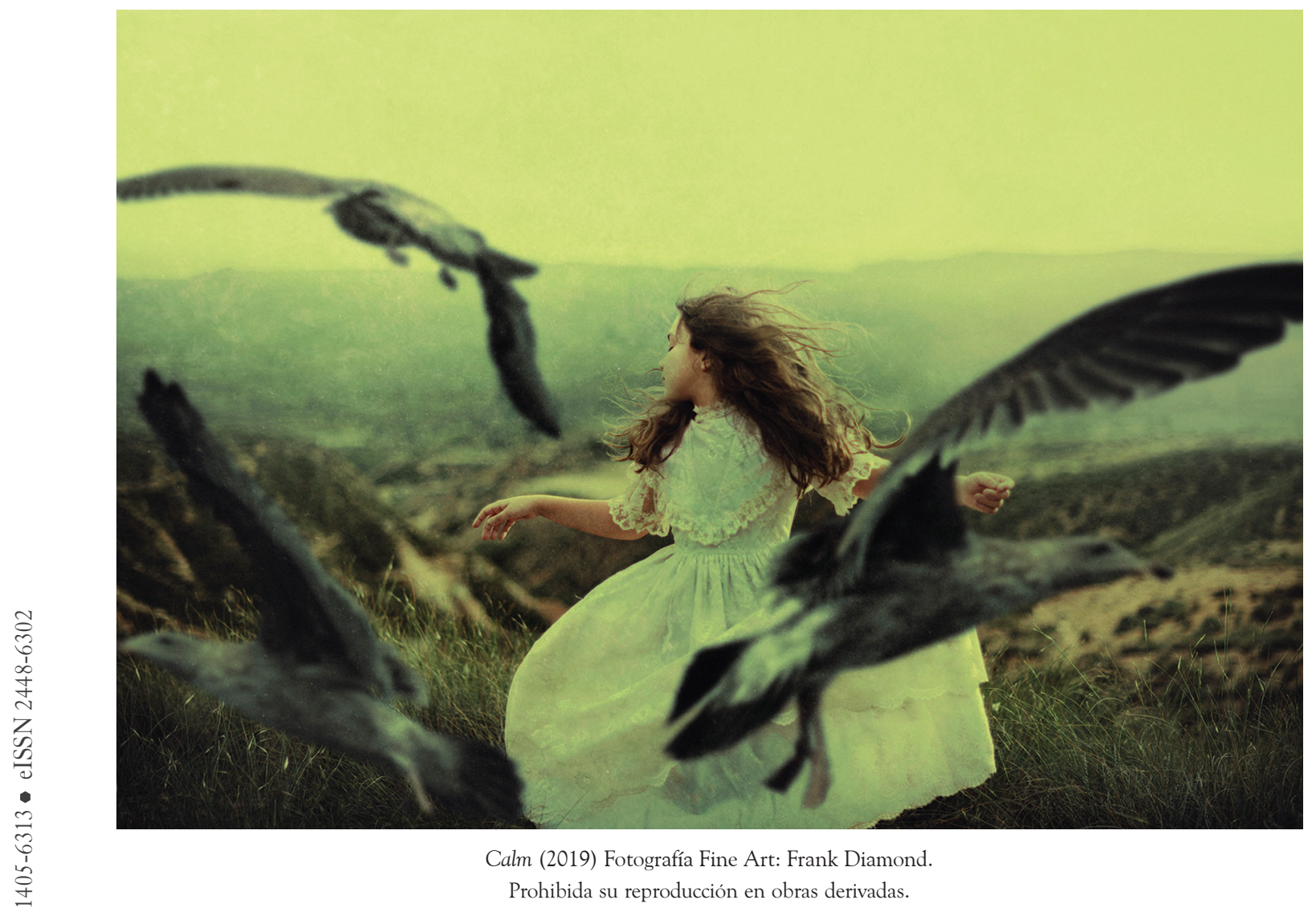

ser enamorado que todo lo espera, como una gracia, un presente otorgado por esa fuente de donde procede; es la donación lo que le satisface y no la búsqueda, como menciona la filósofa en Claros del bosque:

El claro del bosque es un centro en el que no siempre es posible entrar; desde la linde se le mira y el aparecer de algunas huellas de animales no ayuda a dar ese paso. Es otro reino que un alma habita y guarda. Algún pájaro avisa y llama a ir hasta donde vaya marcando su voz. Y se la obedece; luego no se encuentra nada, nada que no sea un lugar intacto que parece haberse abierto en ese solo instante y que nunca más se dará así. No hay que buscarlo. No hay que buscar. Es la lección inmediata de los claros del bosque: no hay que ir a buscarlos, ni tampoco a buscar nada de ellos. Nada determinado, prefigurado, consabido (Zambrano, 1986: 2).
No hay que buscar, sólo dar, como en el amor, que conlleva la absoluta entrega. Producto del instante es el asombro que les provoca, a sus habitantes y a aquellos extranjeros que se atreven a realizar el viaje a este lugar de ensueño, vivir y sentir en la piel a Mogador: las calles laberínticas de la ciudad, el hammam, la plaza caracol, el mercado, los jardines de cada casa son sitios propicios, hasta el aire que se respira en la ciudad lleva el aliento del deseo. No se necesita ser Sonámbulo, sólo basta dejarse conducir por el deseo en constante búsqueda de emociones y pasiones.

La unidad de la que habla María Zambrano se identifica con la perspectiva que tiene Octavio Paz como parte de la consagración del instante: "La poesía no se siente: se dice. O mejor: la manera propia de sentir la poesía es decirla. Ahora bien, todo decir es siempre un decir de algo" (2010: 189). Esto es lo que para Zambrano ocurre en la unidad: un instante, el del poema, donde 
la palabra se funde para darle sentido a cada frase que lo compone y nos conduce a la emoción, a la intensidad; así lo que estamos leyendo sale del texto para que lo aprehendamos en nuestro ser. La poesía se vive, se siente, se manifiesta a partir de la experiencia, tal como ocurre en la prosa de intensidades.

La poesía es incesante, está envuelta por los afectos, por la pasión del alma, es liberación: "de no tener vuelo el poeta, no habría poesía, no habría palabra. Toda palabra requiere de un alejamiento de la realidad a la que se refiere; toda palabra es, también, una liberación de quien la dice" (Zambrano, 2001: 21).

Para la filósofa, el hombre no está presente en sí mismo y necesita estarlo, necesita ser. La poesía sirve como ese puente porque posee la fuerza de lo inagotable, de una verdad nunca conquistada, unidad del instante poético que nos llena de asombro, revelación, razón poética. Para que llegue a nosotros esa realidad basta con vivirla y obtener la experiencia que nos ofrece la existencia, un verdadero saber que se abre a cada persona, revelándose intenso en cada cosa que experimentamos por medio de nuestros sentidos, emociones y sensaciones, tal como la prosa de Alberto Ruy Sánchez: "es un procedimiento de naturaleza poética que hace avanzar la narración, no por las vías del suspenso, que mueve a gran parte de lo que conocemos como narrativa, sino por los caminos accidentados del asombro" (Ruy Sánchez: 1988: 79).

La vida se conduce a partir del deseo, simbolizado mediante la geografía de Mogador. El autor logra expresar así una íntima dimensión del erotismo a partir del lenguaje, la espiral, el laberinto que conduce por un recorrido minucioso de cada lugar, espacios donde se logra imaginar el encuentro amoroso. De ahí que la atmósfera perfecta para que esto suceda sea Mogador, donde prevalece el acto erótico y la vida interior, y los sentidos cobran importancia.

\section{ConClusión}

Poesía y pensamiento se unen como amantes que se necesitan y van siempre a la búsqueda de nuevos caminos por conocer. La espiral de Mogador va acompañada por el laberinto que simboliza ese lugar indeterminado, misterioso, que atrapa; sitio que seduce por su ordenamiento y calles estrechas que giran en círculos hasta llegar al corazón de la ciudad. En este laberinto se ofrece la oportunidad de tomar caminos alternativos que llegan al mismo fin, el centro, sin buscar salida, pues existe la necesidad de estar en este lugar, habitarlo cada vez de diferente manera y hallarse entre estas calles incitantes. Mogador es la amante perfecta, por ello se asocia a la mujer deseada, inaccesible para aquellos incapaces de descifrarla. Estar en ella es un reto, pues exige darle sentido a sus habituales cambios, que se organizan de infinitas maneras. Estas imágenes sensoriales provocan al lector, como si ese universo fuese creado para él y en un cerrar de ojos lo trasportara a la realidad que está leyendo, conducido a este viaje por la imagen que devela, atrapa, desbarata los sentidos más íntimos.

Este mundo es posible porque precisamente de eso se trata sentir la poesía: vivir intensamente a partir del asombro, de las imágenes puestas en cada palabra. Esta prosa va más allá de la razón, se dirige a la sensibilidad, al corazón y muestra la entrega del poeta para mantener viva la llama del deseo.

La minuciosa manera de dibujar con perfecta geometría un conjunto de mosaicos narrativos da pauta para poder recrear el Quinteto de Mogador. Su lectura incita a viajar a lugares jamás imaginados ni pensados, a descubrir emociones mediante la palabra. Con un suspicaz cuidado, el lenguaje se hace imagen, exalta los detalles para revivirlos, suscita sensaciones que coexisten entre poesía y prosa, en un mundo subjetivo que nos lleva hasta el asombro. Esta imagen literaria 
sirve como un puente entre la realidad en la que se encuentra el lector y la que se está descubriendo en cada texto que compone la obra. A partir de esto se crea una nueva visión del mundo, con un enfoque que nos hace capaces de percibir aquellas sensaciones que nos provoca la vida.

\section{REFERENCIAS}

Abeyta, Michael (2007), "Catedrales, nómadas y cuerpos sin órganos: entre Gilles Deleuze y las novelas de Mogador de Alberto Ruy Sánchez", Revista Iberoamericana, vol. LXXIII, núm. 218, pp. 13-27, disponible en: http://www.angelfire. com/ar2/libros/Catedralesnomadas.pdf

Bachelard, Gaston (1993), La poética de la ensoñación, México, FCE.

Bachelard, Gaston (2014), La intuición del instante, México, FCE.

Bundgard, Ana (2000), Más allá de la filosofía. Sobre el pensamiento filosófico-místico de María Zambrano, Madrid, Trotta.

Carrillo Juárez, Carmen Dolores (2004), "La exploración del deseo: recurso metaficcional en Los jardines secretos de Mogador", Revista de Literatura Mexicana Contemporánea, núm. 22, pp. 85-92.

Gingras, Mario (2006), La prosa de intensidades en la narrativa de Alberto Ruy Sánchez: Un habitar poético del mundo, memoria presentada para la obtención del grado de Maestro en Estudios Hispánicos, Université de Montréal, disponible en: https:/papyrus.bib.umontreal.ca/xmlui/handle/1866/18151

Monges Nicolau, Graciela (2004), Hacia una hermenéutica del deseo. Lectura de tres novelas de Alberto Ruy Sánchez, México, Universidad Iberoamericana.

Paz, Octavio (2010), El arco y la lira, México, FCE.

Ruy Sánchez, Alberto (1988), Al filo de las hojas, México, Secretaría de Educación Pública/Plaza y Valdés.

Ruy Sánchez, Alberto (1992), De cuerpo entero, México, Universidad Nacional Autónoma de México.

Ruy Sánchez, Alberto (1994), Cuentos de Mogador, México, Consejo Nacional para la Cultura y las Artes.

Ruy Sánchez, Alberto (2001), Cuatro escritores rituales, México, Consejo Nacional para la Cultura y las Artes.

Ruy Sánchez, Alberto (2015), Quinteto de Mogador, México, Alfaguara.

Zambrano, María (1973), El hombre y lo divino, México, FCE.

Zambrano, María (1986), Claros del bosque, Barcelona, Seix Barral.

Zambrano, María (2001), Filosofía y poesía, México, FCE.
Laiza Sabrina de la Torre Zepeda. Licenciada en Letras Latinoamericanas y Maestra en Humanidades: Estudios Literarios por la Universidad Autónoma del Estado de México (UAEM), México. Estudió la Especialización en Literatura Mexicana en la Universidad Autónoma Metropolitana (UAM), México. Estudiante del Doctorado en Humanidades: Estudios Literarios por la UAEM. Ha participado en congresos nacionales e internacionales. Entre sus publicaciones se encuentra: "Prisión/encierro en El sexto de José María Arguedas y El apando de José Revueltas" (Contribuciones desde Coatepec, núm. 25). 